\title{
Scottish early Holocene vegetation dynamics based on pollen and tephra records from Inverlair and Loch Etteridge, Inverness-shire
}

\author{
Thomas J. Kelly a, Mark Hardiman b, Michael Lovelady a, J. John Lowe a, ${ }^{*}$, Ian P. Matthews a, Simon P.E. Blockley \\ a Department of Geography, Royal Holloway, University of London, Egham, Surrey TW20 OEX, UK \\ b Department of Geography, University of Portsmouth, Buckingham Building, Lion Terrace, Portsmouth PO1 3HE, UK
}

\section{A B S T R A C T}

This paper presents the results of an investigation of early Holocene cryptotephra layers recovered from sediments in two kettle-hole basins at Inverlair (Glen Spean) and Loch Etteridge (Glen Fernisdale). Electron probe micro-analysis (EPMA) of shards from two cryptotephra layers revealed that the uppermost layer in both sequences has a composition similar to the An Druim tephra, first reported from a site in Northern Scotland. We present evidence that distinguishes the An Druim from the chemically very similar early Holocene Ashik tephra. The lowermost layer at Inverlair matches the composition of the Askja-S tephra found in the Faroe Islands, Ireland, Sweden, Germany and Switzerland. This is the first published record of the Askja-S tephra from mainland Scotland. As at other sites, the Askja-S seems to mark a short-lived climatic deterioration, most likely the Pre- Boreal Oscillation: at Inverlair it occurs just above an oscillation represented by a reduction in LOI values and in the abundance of Betula pollen, and by a peak in Juniperus pollen. The lowermost layer at Loch Etteridge has a Katla-type chemistry and extends through the upper part of the Loch Lomond (Younger Dryas/GS-1) Stadial to the Stadial/Holocene transition; it may represent a composite layer which merges the Vedde and Abernethy tephras. One of the key conclusions is that the glacial-melt deposits in the vicinity of Inverlair (kames and kame terraces) were ice-free by c. $10.83 \mathrm{ka}$ (the age of the Askja-S), providing a limiting age on the disappearance of LLR ice in Glen Spean.

\section{Introduction}

Distal tephra layers of Icelandic origin, mostly thin and invisible to the naked eye, have been known from Britain and Ireland for many years (e.g. Dugmore, 1989; Bennett et al., 1992; Dugmore et al., 1995; Hall and Pilcher, 2002; Turney et al., 2006; Pyne- O’Donnell, 2007; Matthews et al., 2011). Since the first discovery of the Vedde Ash on the British mainland (Lowe and Turney, 1997), many of these layers have been identified with the aid of density separation techniques which allow tephra shards to be concen-trated from inorganic sediments, of which they are frequently a small component (Turney, 1998; Blockley et al., 2005). Distal ash layers have been increasingly used to establish isochronous stratigraphic links between environmental records in different parts of Europe, thereby enabling the synchronicity of past climatic events to be assessed (cf. Haflidason et al., 2000; Lowe, 2001; Lowe et al., 2008a; Lane et al., 2011, 2012; Davies et al., 2012). Here we report the discovery of Loch Lomond Stadial (LLS: equivalent to the Younger Dryas) and early Holocene tephra layers from two sites in the Scottish Highlands (Fig. 1), and examine their potential as isochronous markers for establishing the relative timing of early Holocene vegetation and environmental changes in this region. Both of these sites lie close to the mapped limits of the Loch Lomond Readvance (LLR) in Scotland (Fig. 1), which is broadly equivalent in timing to the Younger Dryas Readvance in Scandinavia (Golledge, 2010; Mangerud et al., 2016). At one of these sites we examine the potential of tephra horizons to constrain the timing of ice retreat following the LLR, the maximum limits of which are currently thought to have been reached during the latter part of the LLS (Palmer et al., 2010).

\section{Site locations and methods}

\subsection{Site descriptions}

Inverlair (5685205500 N, $484304300 \mathrm{~W}$ : NN 341 803) is a small kettle-hole basin situated on the southern side of Glen Spean at an altitude of c. $170 \mathrm{~m}$ O.D. (Fig. 2a), roughly $4 \mathrm{~km}$ west of the moraine at Rough Burn, which marks the limit of Loch Lomond Readvance (LLR) ice that led to the formation of the Parallel Roads (shorelines of glacially-dammed lakes) of Glen Roy (Sissons, 1979a; Palmer et al., 2010). The basin lies within an extensive suite of glaciofluvial mounds and terraces deposited by the decaying LLR ice (Sissons, 1979b, 1979c, 2016), an interpretation supported by pollen-stratigraphic investigations conducted in several basins in this general vicinity, which consistently found the earliest deposits to be of early Holocene age (Lowe and Cairns, 1991). For the present study, the site at Inverlair was systemati- cally investigated using a Dutch gouge sampler to locate the deepest part of the basin from which cores of the lowermost metre of sediment infill were subsequently extracted using a Russian coring device (Jowsey, 1966). Pollen analysis of the basal layers was conducted at a higher stratigraphic resolution than in the case of Lowe and Cairns (1991), using the laboratory procedures outlined below.

Loch Etteridge ( 5780003300 N, 480903700 W: NN 689 929) lies at an altitude of c. 300 m O.D. at the head of Glen Fernisdale (Fig. 2b), which presently drains north-eastwards via Allt na Feithe Moire into the Spey river system. The loch, which has a long axis of c. $560 \mathrm{~m}$, and a secondary axis of c. $170 \mathrm{~m}$, is flanked by kames and kame terraces, while a prominent esker runs along the long axis of the loch, in parts protruding above the loch surface. It has been posited that the loch basin represents a large kettle-hole feature (Walker, 1975). Quiescent infill of the loch has occurred at its SW extremity, from where Walker (1975) recovered a full suite of Lateglacial deposits, and a series of radiocarbon dates. The oldest date suggests that the basin has collected sediment since c. $1314 \mathrm{C}$ ka, indicating that the landforms and the lake basin were formed during or immediately following the melting of the Late Devensian ice sheet (Sissons and Walker, 1974).

\subsection{Methods}

Here we present pollen-stratigraphic data for the Loch Lomond Stadial (LLS) and early Holocene parts of the Loch Etteridge sequence and for the upper LLS boundary and Early Holocene from Inverlair. For both records pollen analysis was undertaken at higher resolution than in the records reported by Walker (1975; Etteridge) and Lowe and Cairns (1991; Inverlair).

The Inverlair sequence has not previously been investigated for tephra content, but previous tephrostratigraphical investigations of the Lateglacial sediment succession within the Loch Etteridge basin indicates that 3 or possibly 4 tephra layers occur within deposits of 
Windermere Interstadial age, and two within the Loch Lomond Stadial interval (Lowe et al., 2008b). The cryptotephra study at Loch Etteridge was based on a core sequence recovered from the site in 2007, whereas the pollen investigations were based on a separate core taken in 2008 (see Lovelady, 2008, for further details). Precise correlations between the cores are possible however, through very similar variations in LOI values throughout each sequence (Fig. 3).

Examination of both sequences for the presence of volcanic shards was conducted using a modified version of the heavy flotation method described by Blockley et al. (2005). A scan for tephra shards was initially conducted across $5 \mathrm{~cm}$ vertical intervals; for each $5 \mathrm{~cm}$ interval where tephra shards were detected, contiguous sub-samples of $1 \mathrm{~cm}$ vertical interval were subsequently extracted. Samples were cleaned to remove organic matter such as diatom frustules by floatation in sodium polytungstate solutions of up to $2.25 \mathrm{~g}$ cm_3. Rhyolitic shards were then extracted at a density of $2.55 \mathrm{~g} \mathrm{~cm}$ 3. Residues were mounted in Canada balsam and the number of shards present recorded by microscope examination at 100_ magnification, increased to 400 to confirm shard identifications. The positions of peak shard concentrations were determined, from which sub-samples were subsequently extracted for geochemical analysis. These samples were not ashed or subjected to acid treatments prior to analysis (cf. Blockley et al., 2005). Tephra shards were mounted in epoxy resin and carefully polished to expose shard surfaces, prior to submission for electron probe microanalysis (EPMA) at the Research Laboratory for Archaeology, Oxford University. Whilst it is generally recommended that analyses with totals below $95 \%$ be excluded (cf. Hunt and Hill, 1993), for some tephra layers low shard concentrations and the highly vesicular nature of the recovered shards made it difficult to obtain an adequate number of analyses (e.g. INV-A, Fig. 6), and as such totals above $92 \%$ have been included as supporting information.

Pollen samples were prepared using a dense liquid separation technique (cf. Nakagawa et al., 1998), which differs from the standard method most commonly used for pollen analysis (cf. Fægri et al., 1989). When using density separation, organic matter is separated from heavier minerogenic material by floating at a density of $2.0 \mathrm{~g} \mathrm{~cm} \_3$. The resulting pollen extracts were mounted on slides using glycerine and counted at a magnification of 400 . For the Inverlair sequence a total of $>200$ total land pollen (TLP) was counted for each sample, excepting the basal sample which was counted to $>150$ TLP due to low pollen concentration. For the Loch Etteridge sequence sample counts of between 100 and 200 TLP were obtained. Pollen zones were defined visually but with the aid of preliminary statistical analyses (PCA and DCA).

Loss on ignition (LOI) analyses were undertaken using standard methods (cf. Heiri et al., 2001), to measure the organic content of the sediments contiguously every $1 \mathrm{~cm}$. These were dried overnight before being combusted in a furnace for $2 \mathrm{~h}$ at $550 \mathrm{C}$.

\section{Results}

Both the Inverlair and Loch Etteridge pollen records show the hallmark vegetation succession typical for the early Holocene in Scotland (Figs. 4 and 5). Following the open-ground taxa that developed during the Loch Lomond Stadial - characteristically dominated by pollen of Poaceae, Rumex and Artemisia (pollen assemblage zones LET-2a and 2b, Fig. 5) - the onset of milder conditions allowed the successive invasion of first Empetrum, followed by Juniperus, then Betula and then Corylus (pollen assemblage zones INV-I to INV-IVa, Fig. 4; LET-3a to 4a, Fig. 5). This matches the evidence from other sites in the general vicinity, such as that reported for several sites in Glen Spean and Glen Roy by Lowe and Cairns (1991) and from a site in the Pass of Drumochter around $15 \mathrm{~km}$ due south of Loch Etteridge (Walker, 1975). This succession from open ground taxa to the invasion of birch-hazel woodland following the Loch Lomond Stadial is also recorded in many other sites throughout lowland Scotland and in the southern and central Highlands, and was generally completed within the first millennium of the Holocene (e.g. Walker, 1984; Birks, 1989; Benn et al., 1992). The pollen-stratigraphic data therefore provide secure temporal limits within which the age of the tephra layers, reported next, should fall.

Two discrete distal ash layers were identified in each of the two sequences. The lowermost layer in the Inverlair sequence, INV-A, lies between 11.60 and $11.62 \mathrm{~m}$ depth with a peak concentration of 87 shards per gram of sediment (sh g_1). This lies within the transition from a juniperdominated to a birch-dominated pollen zone (Fig. 4), and well before the onset of Corylus (hazel) pollen deposition, and hence indicates a very early Holocene age. The chemical composition of the INV-A tephra layer most closely matches that of the Askja-S tephra (Fig. 6) previously reported from sites in Sweden (Davies et al., 2003; Lilja et al., 2013), Norway (Pilcher et al., 2005), Ireland (Turney et al., 2006), the Faroe Islands (Lind and Wastega ${ }^{\circ}$ rd, 2011), Germany (Lane et al., 2012) and Switzerland (Lane et al., 2011). This is the first time, however, that this tephra layer has been reported from mainland Scotland. The current best-estimate age for the Askja-S tephra is 10,944-10,716 cal BP (2S; Bronk Ramsey et al., 2015), which supports the early Holocene age inferred from the pollen data.

The upper tephra peak at Inverlair, INV-B, lies between 10.99 and $11.01 \mathrm{~m}$ depth with a peak concentration of 336 sh g_1, 1, and was deposited well after the decline of Empetrum and Juniperus, and after the development of a mixed Betula-Corylus woodland. Its stratigraphic position is similar to that of the upper tephra identified in the Loch Etteridge 2007 core sequence, ETT-B (Figs. 4 and 5), which is confined to between 6.98 and $7.03 \mathrm{~m}$ depth, with a peak concentration of $107 \mathrm{sh}$ g_1. The chemical composition of INV-B and ETT-B are also very similar (Fig. 3; Tables 1 and 2), and both match most closely to the chemical spectrum of the An Druim tephra, previously reported by Ranner et al. (2005) from the site of Lochan An Druim on the north coast of Scotland, with a mean age estimated at c. 9.65 ka BP (see below). This tephra, however, is also similar in chemical composition to that of the early Holocene Ashik tephra, recovered from sites in the Isle of Skye by PyneO'Donnell (2007), which is estimated to have been deposited prior to c. $10.15 \mathrm{ka}$ BP with a most probable age of c. $10.50 \_0.3 \mathrm{ka}$ BP (see below).

Although the mean ages of these two layers are relatively close, we are able to discriminate between them through two indepen-dent lines of evidence for stratigraphic superposition. The first is the stratigraphic position of the Ashik tephra relative to the Saksunarvatn Ash. PyneO'Donnell (2007), who first reported the early Holocene Ashik tephra from three sites located on the islands of Skye and Mull, off the west coast of Scotland, demonstrated that it lies below a distinctive tephra layer he assigned to the Saksunarvatn Ash. The chemical data available to him at the time did not, however, conclusively support this latter correlation, as there were clear outlier values for both TiO2 and $\mathrm{K} 2 \mathrm{O}$ (Fig. 7). Subsequent research has augmented the data now available for the Saksunarvatn Ash (Lind and Wastega ${ }^{\circ}$ rd, 2011; Brooks et al., 2012; Bramham-Law et al., 2013; Bronk Ramsey et al., 2015), while new analytical data are reported here (see Table S2) which have also been obtained from the layer originally assigned by Pyne- O'Donnell (2007) to the Saksunarvatn Ash (reported stratigraphi-cally in Brooks et al., 2012). These new data have been measured against internationally recognised analytical standards (Jochum et al., 2006; Table S2), and cluster 
more closely with other reported analyses for this ash (Fig. 7), supporting Pyne-O'Donnell's initial suggestion. The Ashik tephra therefore predates the Saksunarvatn Ash, the current best-estimate age for which is 10,257-10,056 cal BP (2s; Bronk Ramsey et al., 2015).

Pollen stratigraphy provides the second line of evidence. The Ashik tephra in the records from Skye and Mull clearly pre-dates the arrival of Corylus (hazel), but the tephra layers INV-B and ETT-B post-date the establishment of Corylus in each locality. This is also the case with the An Druim tephra layer in the Lochan An Druim sequence (Birks, 1989; Ranner et al., 2005), which has been dated to c. 9781-9538 cal BP, and while this date could be questioned because it is based on an age model using both AMS dates of plant macrofossils alongside reservoircorrected bulk sediment samples (Ranner et al., 2005), it does nevertheless accord with the evidence that indicates that the Corylus rise in Scotland coincides with or post-dates the age of the Saksunarvatn Ash. Moreover in some Scottish sequences where the Saksunarvatn Ash is reported it is also stratigraphically associated with the Corylus rise (Bunting, 1994; Tallantire, 2002). All the available evidence therefore suggests that the Ashik tephra dates to the very early Holocene, before the Corylus rise in the Scottish Highlands, while the An Druim tephra is significantly younger. Our evidence therefore strongly indicates that the INV-B and ETT-B tephra layers correlate with the An Druim tephra.

The lowermost tephra layer in the Loch Etteridge sequence (ETT-A) is located between 7.58 and $7.63 \mathrm{~m}$ depth in the 2007 core, but has three separate peaks in shard concentrations of 22, 30 and 43 sh g_1 at depths of 7.53-7.54, 7.56-7.58 and 7.61-7.62 m respectively (Fig. 3). Geochemical data for these layers are provided in Table 2, although only two analyses were obtained for the lowest layer (7.61-7.62 m) due to the low shard numbers recovered. The data overall suggest a close affinity with the chemical composition of the Vedde Ash, sourced from the Katla volcano in Iceland (Mangerud et al., 1984). The Vedde Ash is widely recorded in Scotland, and consistently falls within the middle part of the Loch Lomond Stadial (Younger Dryas, GS-1) interval (e.g. Lowe and Turney, 1997; Wastega ${ }^{\circ}$ rd et al., 2000; Davies et al., 2001). In the 2007 Etteridge core, however, ash with a Katla signature can be traced continuously from the middle of the LLS stratigraphic unit to the Stadial/Holocene boundary (pollen zones LET-2a to 3a, Fig. 5). As such, a correlation with the Abernethy tephra (MacLeod et al., 2015), which has a composition similar to that of the Vedde Ash (Fig. 6) but lies close to the Holocene boundary, is also possible. MacLeod et al. (2015) have shown that there are two distinct layers with a Katla chemical signature at around this time: the Vedde Ash, and a younger Abernethy tephra, the latter dating very close to the Stadial/Holocene transition (11,721-11,231 cal BP; Bronk Ramsey et al., 2015). In fact, they distinguish both of these layers as separate peaks in the Loch Etteridge sequence, but from a different core to the one studied here - one that shows a fuller and better resolved Lateglacial record, within which five separate ash layers were identified, initially named LET-1 to LET-5, but re-labelled here as LET-1t to LET-5t to distinguish them from the pollen zones reported for the same site. The LET-4t and LET-5t layers were assigned to the Vedde Ash and Abernethy tephra respectively (Lowe et al., 2008b; MacLeod et al., 2015). We consider it possible that the ETT-A ash layer reported in the present study is a merged composite of both the LET-4t (Vedde Ash) and LET-5t (Abernethy tephra) layers, probably as a result of a slower rate of sedimenta-tion during the LLS than in the case of the core studied by MacLeod et al. (2015). 4.

Significance of the results

4.1. Tephrostratigraphic implications

The data presented here suggest that some early Holocene tephra layers may be more widespread in Scotland than has been established hitherto. The Askja-S tephra, identified for the first time on the Scottish mainland in the Inverlair sequence, has a wide distribution in northern Europe, in which Scotland has a central position (Bronk Ramsey et al., 2015, Fig. 1). The possibility that this tephra could link other Scottish early Holocene records should therefore be explored. The An Druim tephra may also be present in a sequence investigated on the shores of Loch Laggan, located between Inverlair and Etteridge, but on stratigraphic grounds it is more difficult to discount a correlation with the Ashik tephra at this site (MacLeod, 2008). The data provided here, however, indicate that the early Holocene rise in Corylus pollen can provide a reliable biostratigraphical marker for distinguishing between layers of the An Druim and Ashik tephras, at least for sites in Scotland. This is significant, for up until now differentiation of these two tephra layers was based mainly on the radiocarbon dates obtained from An Druim. This study therefore strengthens the case for separating these two tephra layers, as proposed in the INTIMATE event stratigraphy scheme (Blockley et al., 2014).

Lind and Wastega ${ }^{\circ} \mathrm{rd}$ (2011) speculated that the An Druim tephra could have an unknown bimodal shard chemistry, but the geochemical data from Inverlair lend only limited support to this. Almost all of the shards analysed in our work were indistinguish-able in chemical composition from that of the An Druim tephra reported by Ranner et al. (2005). In both the Inverlair and Loch Etteridge An Druim records, only a single shard shows a higher proportion of $\mathrm{MgO}$ and $\mathrm{CaO}$, and a lower proportion of $\mathrm{FeO}$ (Tables 1 and 2), which more closely matches the chemical composition of the $\mathrm{H} \varnothing$ vdarhagi tephra, reported by Lind and Wastega ${ }^{\circ}$ rd (2011). If the Høvdarhagi and An Druim tephra layers represent different components of the same eruption, then this would extend this marker to the Faroe Islands, but this would mean that the area over which this tephra was deposited still only covers a narrow strip from Iceland towards the north of Scotland; the An Druim/Høvdarhagi isochron would therefore continue to be of limited use for connecting sites across northern Europe.

\subsection{Palaeoenvironmental implications}

The discovery of the Askja-S tephra in the Inverlair sequence provides an extremely important limiting age for the disappear-ance of Loch Lomond Readvance glacier ice from Glen Spean: the Inverlair kettle-hole basin must have been deglaciated and receiving sediment by 10,830 $57 \mathrm{cal}$ BP. What is more, below the horizon in which the Askja-S tephra is found, more than $10 \mathrm{~cm}$ of sediment had already accumulated, containing pollen-stratigraphic evidence for the development of Empetrum heath followed by the invasion of juniper scrub (Fig. 4; Table 3). It is not known how long these vegetation phases persisted locally, but this evidence suggests that the age of the Askja-S tephra is a minimum value for the time of deglaciation of this part of Glen Spean. Inverlair lies within the reconstructed tephra footprint of the Askja-S tephra proposed by Davies et al. (2012), so it is somewhat surprising that it has not been discovered at other sites on the Scottish mainland, such as further north (e.g. Ranner et al., 2005), or to the west on Skye and Mull (e.g. Pyne-O'Donnell, 2007) or in the nearby Loch Laggan site (MacLeod, 2008). It may be that this reflects different rates of sedimentation between basins, and future studies should perhaps explore basins with more highly resolved early Holocene records, to test for the possible wider occurrence of this tephra in Scotland.

At Ha"sseldalen Port in Sweden, the Askja-S tephra was found to overly a reduction in organic carbon content (in core 3) thought to represent the Pre-Boreal Oscillation (PBO), an interpretation supported by a coincident reduction in Pinus pollen percentages (Wohlfarth et al., 2006). In the Inverlair record, the Askja-S tephra coincides with a decrease in LOI values and lies immediately above a reversal in Betula pollen 
percentages. It appears, therefore, that the Askja-S tephra may provide an important isochron for testing the timing of events proposed as correlatives of the PBO in northern Europe.

The Askja-S tephra also directly overlies the peak in Juniperus in INV-2a (Fig. 4; Table 3). Although this will not be discussed in detail here, it could imply that the timing of the juniper peak in parts of Scotland occurred close to the PBO, and that the Askja-S tephra might therefore provide a more reliable means than radiocarbon dating (cf. Tipping, 1987) for testing the synchronicity of the juniper peak throughout Scotland. Juniper is a light-demanding shrub that would benefit from a decline in tree cover, and is capable of tolerating the more frequent frosts and cooler conditions which probably characterised the PBO (Thomas et al., 2007). This pattern of decreasing Betula and increasing Juniperus has also been seen in early Holocene pollen records from other sites in Britain (e.g. Walker et al., 1993).

Corylus is more abundant in the Inverlair core than at Loch Etteridge; the catchment of the Loch Etteridge basin is far larger than at Inverlair and so this feature is unlikely to be explained by differences in pollen transport area (cf. Davis, 2000). It is possible that Corylus was more abundant around Inverlair either because the local edaphic conditions were more favourable or because Inverlair lies at a lower altitude. However, in terms of the timing of the Corylus rise, at both sites the increase in Corylus lies stratigraphically between the Askja-S and An Druim tephra layers, indicating an early Holocene expansion. This largely agrees with the studies of Boyd and Dickson (1986) and Edwards and Berridge (1994), which concluded that Corylus expanded into Scotland during the early Holocene.

The Etteridge sequence differs from that at Inverlair in that it clearly shows an increase in Pinus pollen towards the top of the core (zone LET5). The initial increase in Pinus is seen in zone LET-4c, which immediately overlies the An Druim tephra: based on the date given by Ranner et al. (2005) this suggests that Pinus began to expand in this area shortly after 9781-9538 cal BP. Although Pinus pollen can be transported long distances on the wind, pollen percentages exceed $40 \%$ in LET- 5 and this likely indicates local presence. In a review of the post-glacial dynamics of Pinus, Cheddadi et al. (2006) suggest that Pinus did not arrive in Scotland until after c. 8000 cal BP (a threshold of $5 \%$ was used for pollen data), and so the establishment of Pinus near Loch Etteridge may have occurred earlier than at other Scottish sites.

\section{Conclusions}

The results presented here add to the mounting evidence that indicates cryptotephra isochrons have much to offer for synchro-nising Lateglacial and early Holocene records in Scotland. The focus here has been on the early Holocene, a difficult period to examine in detail because of the rapid environmental transformations that took place: radiocarbon dating has generally proved too blunt an instrument for establishing the precise timing of events during this period (Lowe \& Walker, 2000). Attempts to develop an index of relative dating of early Holocene events have hitherto been based primarily on pollen-stratigraphic comparisons (e.g. Walker and Lowe, 1981; Lowe and Cairns, 1991; Benn et al., 1992), which assume an orderly sequence of colonisation of the landscape by plants following rapid thermal improvement around 11,700 years ago (Walker et al., 2009). The weakness with this assumption, however, is that rates of plant colonisation and of the emergence of stable plant communities depend on a number of factors, including seasonal differences in ambient temperature, shelter from or exposure to the elements, distance from plant refugia, soil or substrate type and the role of soil bacteria (Matthews, 1992; Schmidt et al., 2008). An independent test of this approach is therefore required, and tephra isochrons appear to offer the best prospect for this. We have reported the first discovery of the Askja- S tephra on the Scottish mainland, which brings to five the number of early Holocene tephra isochrons detected in Scottish lake sediments: from oldest to youngest these are the Abernethy tephra (MacLeod et al., 2015), the Askja-S tephra, the Ashik tephra (Pyne- O'Donnell, 2007), the Saksunarvatn Ash (Pyne-O'Donnell, 2007, 2011) and the An Druim tephra (Ranner et al., 2005; Ranner, 2005).

Our data suggest that the Askja-S and An Druim tephras may be more widely dispersed in Scotland than previously supposed. This is important because the Askja-S tephra has now been identified at several widely separated sites across Europe, has a distinctive geochemistry, and seems to mark the end of the PBO, and hence is gradually emerging as a useful early Holocene isochron (Davies et al., 2012). The difficulty of attaining reliable radiocarbon dates during this time-frame makes this discovery doubly significant (cf. Bjo" rck et al., 1997). The potential of the An Druim tephra is difficult to assess at this stage, for it has been discovered at few sites so far, and there may be problems of distinguishing this ash from others with similar chemistry. Regarding the separation of the geochemically similar Ashik and An Druim tephras, there appear to be subtle differences in shard geochemistry which might be useful for making a distinction. However, in this case, pollen stratigraphy may provide the best means of differentiating between these ash layers in records from Scottish sites, as the An Druim tephra seems to have been deposited well after the regional Corylus rise (Table 3).

With reference to the theme of this special issue of the Proceedings of the Geologists' Association, perhaps the most vital finding is the limiting date provided by the Askja-S tephra for the timing of deglaciation in the area after the Loch Lomond Readvance. The site of Inverlair lies within a suite of kames and kettle-holes formed during the retreat of the LLR ice margin, and the earliest sediments at Inverlair suggest deposition in a small pond. This means that both the glacier margin and the ice-dammed $260 \mathrm{~m}$ lake had vacated the area by c. $10.83 \mathrm{ka}$, the age assigned to the Askja-S tephra (Bronk Ramsey et al., 2015).

\section{Acknowledgements}

This research was predominantly conducted for independent research projects, components of the NERC-recognised MSc degree in Quaternary Science, and based at Royal Holloway, University of London (ML acknowledges additional support in the form of a NERC MSc support grant). We would like to acknowledge the help of Robyn Christie, Adrian Palmer, Alison MacLeod, Chris Satow, Vicky Smith (Oxford), and Elaine Turton for guidance in various technical aspects of the work.

\section{References}

Andrews, J.T., Geirsdottir, A., Hardardottir, J., Principato, S., Gronvold, K., Kristjansdottir, G.B., Helgadottir, G., Drexler, J. and Sveinbjornsdottir, A. 2002. Distribution, sediment magnetism and geochemistry of the Saksunarvatn (10,180 +/- 60 cal. yr BP) tephra in marine, lake, and terrestrial sediments, northwest Iceland. Journal of Quaternary Science, 17, 731-745.. 
Benn, D.I., Lowe, J.J., Walker, M.J.C. 1992. Glacier response to climatic change during the Loch Lomond Stadial and early Flandrian: geomorphological and palynological evidence from the Isle of Skye, Scotland. Journal of Quaternary Science, 7, 125-144.

Benn, D., and Ballantyne, C.K. 2005. Palaeoclimatic reconstruction from Loch Lomond Readvance glaciers in the West Drumochter Hills, Scotland. Journal of Quaternary Science, 20, 577-592.

Bennett, K.D., Boreham, S., Shárp, M.J., and Switsur, V.R. 1992. Holocene history and environment, vegetation, and human settlement on Catta Ness, Lunnasting, Shetland. The Holocene, 80, 241-273.

Birks, H.J.B. 1989. Holocene isochrones maps and patterns of tree spreading in the British Isles. Journal of Biogeography, 16, 503-540.

Björk, S., Rundgren, R., Ingólfsson, Ó., \& Funder, S. 1997. The Preboreal oscillation around the Nordic Seas: terrestrial and lacustrine responses. Journal of Quaternary Science, 12, 455-465.

Bjorck, J. and Wastegård, S. 1999. Vegetational changes and tephrochronology in eastern middle Sweden during the last glacial-interglacial transition. Journal of Quaternary Science, 14, 399-410..

Blockley, S.P.E, Pyne-O'donnell, S.D.F, Lowe, J.J, Matthews, I.P, Stone, A, Pollard, A.M, Turney, C.S.M, \& Molyneux, E.G. 2005. A new and less destructive laboratory procedure for the physical separation of distal glass tephra shards from sediments. Quaternary Science Reviews, 24, 1952-1960.

Boston, C.M., 2012. A glacial geomorphological map of the Monadhliath Mountains, Scotland. Journal of Maps, 8, 437-444.

Boyd, W.E., and Dickson, J.H. 1986. Patterns in the Geographical Distribution of the Early Flandrian Corylus Rise in Southwest Scotland. New Phytologist, 102, 615-623.

Bramham-Law, CWF, Theuerkauf, M, Lane, CS, and Mangerud, J. 2013. New findings regarding the Saksunarvatn Ash in Germany. Journal of Quaternary Science, 28, 248-257.

Bronk Ramsey, C.B., Albert, P.A., Blockley, S.P.E., Hardiman, M., Housley, R.A., Lane, C.S., Lee, S., Matthews, I.P., Smith, V.C., Lowe, J. 2015 Improved age estimates for important Late Quaternary European tephra horizons in the RESET lattice. Quaternary Science Reviews, 118, 18-32.

Brooks, S.J., Matthews, I.P., Birks, H.H., Birks, H.J.B., 2012. High resolution Lateglacial and early-Holocene summer air temperature records from Scotland inferred from chironomid assemblages. Quaternary Science Reviews, 41, 67-82.

Brown, V.H., Evans, D.J.A., Vieli, A. \& Evans, I.S. 2013. The Younger Dryas in the English Lake District: reconciling geomorphological evidence with numerical model outputs. Boreas 42, 1022-1042.

Bunting, M.J. 1994. Vegetation history of Orkney, Scotland; pollen records from two small basins in west Mainland. New Phytologist, 128, 771792.

Cheddadi, R., Vendramin, G.G., Litt, T., Francois, L., Kageyama, M., Lornetz, S., Laurent, J-M., de Beaulieu, J-L., Sadori, L., Jost, A., and Lunt, D. 2006. Imprints of glacial refugia in the modern genetic diversity of Pinus sylvestris. Global Ecology and Biogeography 15, $271-282$.

Davies, S.M., Turney, C.S.M., and Lowe, J.J. 2001. Identification and significance of a visible, basalt-rich Vedde Ash layer in a Late-glacial sequence on the Isle of Skye, Inner Hebrides, Scotland. Journal of Quaternary Science, 16, 99-104

Davies, S.M., Wastegård, S., \& Wohlfarth, B. 2003. Extending the limits of the Borrobol Tephra to Scandinavia and detection of new early Holocene tephras. Quaternary Research, 59, 345-352.

Davies, S.M., Abbott, P.M., Pearce, N.J.G., Wastegård, S., \& Blockley, S.P.E. 2012. Integrating the INTIMATE records using tephrochronology: rising to the challenge. Quaternary Science Reviews, 36, 11-27.

Dugmore, A. 1989. Icelandic volcanic ash in Scotland. Scottish Geographical Magazine, 105, 168-172

Dugmore, A.J., Larsen, G. and Newton, A.J. 1995: Seven tephra isochrones in Scotland. The Holocene, 5, 257-66

Dugmore, A.J. and Newton, A.J. 1997. Holocene tephra layers in the Faroe Islands. Frodskaparrit, 45, 141-154..

Fægri, K., Iversen, J., Kaland, P.E., \& Krzywinski, K. 1989. Textbook of Pollen Analysis. John Wiley, Chichester, 328 pp.

Giesecke, T., Bennett, K.D., Birks, H.J.B, Bjune, A.E., Bozilova, E., Feurdean, A., Finsinger, W., Froyd, C., Pokorny, P., Rösch, M., Seppä, H., Tonkov, S., Valsecchi, V., \& Wolters, S. 2011. The Pace of Holocene vegetation change - testing for synchronous development. Quaternary Science Reviews, 30, 2805-2814. 
Golledge, N.R., 2010. Glaciation of Scotland during the Younger Dryas: a review. Journal of Quaternary Science 25, 550-566.

Haflidason, H., Eiriksson, J., Van Krefeld, S. 2000. The tephrochronology of Iceland and the North Atlantic region during the Middle and Late Quaternary: a review. Journal of Quaternary Science 15, 3-22.

Hall, V.A., \& Pilcher, J.R. 2002. Late-Quaternary Icelandic tephra in Ireland and Great Britain: detection, characterisation, and usefulness. The Holocene, 12, 223-230.

Heiri, O., Lotter, A.F., \& Lemcke, G. 2001. Loss on ignition as a method for estimating organic and carbonate content in sediments: reproducibility and comparability of results. Journal of Paleolimnology, 25, 101-110.

Jochum, K.P., Stoll, B., Herwig, K., Willbold, M., Hofmann, A., Amini, M., Aarburg, S., Abouchami, W., Hellebrand, E., Mocek, B., Raczek,I., Stracke, A., Alard, O., Bouman, C., Becker, S., Ducking, M., Bratz,H., Klemd, R., de Bruin, D., Canil, D., Cornell, D., de Hoog, C.-J.,Dalpe, C., Danyushevsky, L., Eisenhauer, A., Gao, Y., Snow, J.E., Groschopf, N., Gunther, D., Latkoczy, C., Guillong, M., Hauri, E.H., Hofer, H.E., Lahaye, Y., Horz, K., Jacob, D.E., Kasemann, S.A., Kent, A.J.R., Ludwig, T., Zack, T., Mason, P.R.D., Meixner, A., Rosner, M., Misawa, K., Nash, B.P., Pfander, J., Premo, W.R., Sun, W.D., Tiepolo, M., Vannucci, R., Vennemann, T., Wayne, D., Woodhead, J.D. 2006. MPI-DING reference glasses for in situ microanalysis: new reference values for element concentrations and isotope ratios. Geochemistry Geophysics and Geosystems, 7, Q02008.

Jowsey, P.C. 1966. An Improved Peat Sampler. New Phytologist, 65: 245-248

Koren, J.H., Svendsen, J.I., Mangerud, J. and Furnes, H. 2008. The Dimna Ash - A 12.8 C-14 ka-old volcanic ash in Western Norway. Quaternary Science Reviews, 27, 85-94.

Lane, C.S., Blockley, S.P.E., Bronk Ramsey, C., Lotter, A.F., 2011. Tephrochronology and absolute centennial scale synchronisation of European and Greenland records for the last glacial to interglacial transition: a case study of Soppensee and NGRIP. Quaternary International 246, 145156.

Lane, C.S., De Clerk, P., \& Cullen, V.L. 2012. A tephrochronology for the Lateglacial palynological record of the Endinger Bruch (Vorpommern, north-east Germany). Journal of Quaternary Science 27, 141-149.

Lilja, C., Lind, E. M., Morén, B. \& Wastegård, S. 2013. A Lateglacial-early Holocene tephrochronology for SW Sweden. Boreas 42, 544-554.

Lind, E.M., \& Wastegård, S. 2011. Tephra horizons contemporary with short early Holocene climate fluctuations: New results from the Faroe Islands. Quaternary International, 246, 157-167.

Lloyd, J.M., Bentley, M.J., Nordahl, H., Newton, A.J., Tucker, O. and Zong, Y. 2009. Lateglacial to Holocene Relative Sea-Level Changes in the Bjarkarlundur Area near Reykholar, Northwest Iceland. Journal of Quaternary Science, 24, 816-831.

Lohne, O.S., Mangerud, J., Birks, H.H. 2013. Precise 14C ages of the Vedde and Saksunarvatn ashes and the younger Dryas boundaries from western Norway and their comparison with the Greenland Ice Core (GICC05) chronology. Journal of Quaternary Science 28, 490-500.

Lovelady, M. 2008. Reconstructing high resolution environmental change during the LGIT and early Holocene at Loch Etteridge and Loch Laggan, Scotland. Unpublished MSc thesis, Royal Holloway, University of London.

Lowe, J.J. 2001. Abrupt climatic changes in Europe during the last glacial-interglacial transition: the potential for testing hypotheses on the synchroneity of climatic events using tephrochronology. Global and Planetary Change, 30, 73-84.

Lowe, J.J., Albert, P.G., Hardiman, M., Macleod, A., Blockley, S., Pyne-O'Donnell., S. 2008. Tephrostratigraphical investigations of the basal sediment sequence at Loch Etteridge. In: Palmer, A.P., Lowe, J.J. \& Rose, J., The Quaternary of Glen Roy and Vicinity Field Guide. Quaternary Research Association, London.

Lowe, J.J. \& Cairns, P. 1991. New pollen-stratigraphic evidence for the deglaciation and lake drainage of the Glen Roy-Glen Spean area. Scottish Journal of Geology 27, 41-56.

Lowe, J.J., Rasmussen, S.O., Björk, S., Hoek, W.Z., Steffensen, J.P., Walker, M.J.C., Yu, Z.C., \& The Intimate Group. 2008. Synchronisation of palaeoenvironmental events in the North Atlantic region during the Last Termination: a revised protocol recommended by the INTIMATE group. Quaternary Science Reviews 27, 6-17.

Lowe J.J., \& Turney, C.S.M. 1997. Vedde Ash layer discovered in a small lake basin on the Scottish mainland. Journal of the Geological Society of London, 154, 605-612. 
Macleod, A. 2008. Tephrostratigraphy of the Loch Laggan East lake sequence. In Palmer, A.P., Lowe, J.J., \& Rose, J. (eds) The Quaternary of Glen Roy and Vicinity, Field Guide. Quaternary Research Association, London, 83-91.

MacLeod, A., Matthews, I.P., Lowe, J.J., Palmer, A.P., and Albert, P.G. 2015. A second tephra isochron for the Younger Dryas period in northern Europe: The Abernethy Tephra. Quaternary Geochronology 28, 1-11

Mangerud, J., Lie, S.E., Furnes, H., Kristiansen, I.L., and Lomo, L. 1984. A Younger Dryas ash bed in western Norway and its possible correlations with tephra in cores from the Norwegian Sea and the North Atlantic. Quaternary Research, 21, 85-104.

Mangerud, J., Furnes, H., and Johansen, J. 1986. A 9,000 year old ash bed on the Faroe Islands. Quaternary Research, 26, 262-265.

Mangerud, J., Aarseth, I., Hughes, A.L.C. et al. 2016. A major re-growth of the Scandinavian Ice Sheet in western Norway during AllerødYounger Dryas. Quaternary Science Reviews, 132, 175-205.

Matthews, J.A. 1992. The Ecology of Recently Deglaciated Terrain, Cambridge Studies in Ecology, Cambridge University Press, Cambridge \& New York.

Matthews, I.P., Birks, H.H., Bourne, A.J., Brooks, S.J., Lowe, J.J., MacLeod, A., Pyne-O'Donnell, S.D.F., 2011. New age estimates and climatostratigraphic correlations for the Borrobol and Penifiler tephras: evidence from Abernethy Forest Scotland. Journal of Quaternary Science, 26, 247-252.

Nakagawa, T., Brugiapaglia, E., Digerfeldt, G., Reille, M., Beaulieu, J.-L. De, \& Yasuda, Y. 1998. Dense-media separation as a more efficient pollen extraction method for use with organic sediment/deposit samples: comparison with the conventional method. Boreas, 27, 15-24.

O'Donnell, S.D.F. 2007. Three new distal tephras in sediments spanning the Last Glacial-Interglacial Transition in Scotland. Journal of Quaternary Science, 22, 559-570.

O'Donnell, S.D. F. 2011. The taphonomy of Last Glacial-Interglacial Transition (LGIT) distal volcanic ash in small Scottish lakes. Boreas, 40, 131-145.

Palmer, A.P., Rose, J., Lowe, J.J., and MacLeod, A. 2010. Annually resolved events of Younger Dryas glaciation in Lochaber (Glen Roy and Glen Spean), Western Scottish Highlands. Journal of Quaternary Science, 25, 581-596

Pearce, D. 2014. Reconstructing Younger Dryas glaciation in the Tweedsmuir Hills, Southern Uplands, Scotland: Style, dynamics and palaeoclimatic implications (PhD thesis). Institute of Science and the Environment, University of Worcester, UK.

Pearce, N.J.G., Abbott, P.M., Martin-Jones, C. 2014. Microbeam methods for the analysis of glass in fine-grained tephra deposits: a SMART perspective on current and future trends. Geological Society of London, Special Publication 398, 29-46.

Pilcher, J., Bradley, R.S., Francus, P., \& Anderson, L. 2005. A Holocene tephra record from the Lofoten Islands, Arctic Norway. Boreas 34, 136156.

Pyne-O'donnell, S.D.F. 2007. Three new distal tephras in sediments spanning the Last Glacial-Interglacial Transition in Scotland. Journal of Quaternary Science 22, 559-570.

Pyne-O'donnell, S.D.F. 2011. The taphonomy of Last Glacial-Interglacial Transition (LGIT) distal volcanic ash in small Scottish lakes. Boreas, 40, 131-145

Ranner, P.H, Allen, J.R.M, Huntley, B. 2005. A new early Holocene cryptotephra from northwest Scotland. Journal of Quaternary Science 20, 201-208.

Ranner, P.H. 2005. Lateglacial and early Holocene environmental changes along the Northwest European continental margin. PhD thesis, Durham University. Available at Durham E-Theses Online:http://etheses.dur.ac.uk/2883/

Rasmussen, S.O., Andersen, K.K., Svensson, A.M., Steffensen, J.P., Vinther, B.M., Clausen, H.B., Siggaard-Andersen, M.-L., Johnsen, S.J., Larsen, L.B., Dahl-Jensen, D., Bigler, M., Röthlisberger, R., Fischer, H., Goto-Azuma, K., Hansson, M.E., \& Ruth, U. 2006. A new Greenland ice core chronology for the last glacial termination. Journal of Geophysical Research 111, D06102.

Schmidt, S.K., Reed, S.C., Nemergut, D.R., Grandy, A.S., Cleveland, C.C., Weintraub, N.N., Hill, A.W., Costello, E.K., Meyer, A.F., Neff, J.C., Martin, A.M. 2008. The earliest stages of ecosystem succession in high-elevation (5000 metres above sea level), recently deglaciated soils. Proceedings of the Royal Society, series B 275, 2793-2802.

Sissons, J.B. and Walker, M.J.C. 1974. Lateglacial site in the central Grampian Highlands. Nature, 249, 822-824.

Sissons, J.B. 1974. A Late-glacial ice cap in the Central Grampians, Scotland. Transactions of the Institute of British Geographers, 62, 95-114. 
Sissons, J.B. 1979a. The Limits of the Loch Lomond Advance in Glen Roy and vicinity. Scottish Journal of Geology, 15, 31-42.

Sissons, J.B. 1979b. Catastrophic lake drainage in Glen Spean and the Great Glen, Scotland. Journal of the Geological Society of London, 136, 215-224.

Sissons, J.B. 1979c. The later lakes and associated fluvial terraces of Glen Roy, Glen Spean and vicinity. Transactions of the Institute of British Geographers, New Series 4, 12-29.

Sissons, J.B., Walker, M.J.C. 1974. Late glacial site in the central Grampian Highlands. Nature, 249, 822-824.

Tallantire, P.A. 2002. The early-Holocene spread of hazel (Corylus avellana L.) in Europe north and west of the Alps: an ecological hypothesis. The Holocene, 12, 81-96

Thomas, P.A., El-Barghathi, M., \& Polwart, A. 2007. Biological Flora of the British Isles: Juniperus communis L. Journal of Ecology, 95, 14041440.

Tipping, R.M. 1987. The prospects for establishing synchroneity in the early postglacial pollen peak of Juniperus in the British Isles. Boreas, 16, 155-163.

Tomlinson, E.L., Smith, V.C., Albert, P.G., Aydar, E., Civetta, L., Cioni, R., Çubukçu, E., Gertisser, R., Isaia, R., Menzies, M.A., Orsi, G., Rosi, M., Zanchetta, G. 2015. The major and trace element glass compositions of the productive Mediterranean volcanic sources: tools for correlating distal tephra layers in and around Europe. Quaternary Science Reviews, 118, 48-66.

Tomlinson, E.L. , Thordarson, T. ., Mueller, W., Thirlwall, M., Menzies, M.A. 2010. Microanalysis of tephra by LA-ICP-MS - Strategies, advantages and limitations assessed using the Thorsmork ignimbrite (Southern Iceland). Chemical Geology, 279, 73-89.

Turney, C.S.M. 1998. Extraction of rhyolitic component of Vedde microtephra from minerogenic lake sediments. Journal of Paleolimnology 19, 199-206.

Turney, C.S.M. Van Den Burg, K., Wastegård, S., Davies, S.M., Whitehouse, N.J., Pilcher, J.R., \& Callaghan, C. 2006. North European last glacialinterglacial transition (LGIT; 15-9 ka) tephrochronology: extended limits and new events. Journal of Quaternary Science, 21, $335-345$.

Walker, M.J.C. 1975. Lateglacial and Early Postglacial environmental history of the Central Grampian Highlands, Scotland. Journal of Biogeography, 2, 265-284.

Walker, M.J.C. 1984. Pollen analysis and Quaternary research in Scotland. Quaternary Science Reviews, 3, 369-404.

Walker, M.J.C., Griffiths, H.I., Ringwood, V., \& Evans, J.G. 1993. An early-Holocene pollen, mollusc and ostracod sequence from lake marl at Llangorse Lake, South Wales, UK. The Holocene, 3, 138-149.

Walker, M., Johnsen, S., Rasmussen, S.O., Steffensen, J-P., Popp, T., Gibbard, P., Hoek, W., Lowe, J., Andrews, J.T., Björck, S., Cwynar, L., Hughen, K., Kershaw, P., Kromer, B., Litt, T., Lowe, D.J., Nakagawa, T., Newnham, R., Schwander, J. $2009 . \quad$ Formal definition and dating of the base of the Holocene using the Greenland NGRIP ice core and selected auxiliary records. Journal of Quaternary Science, 24, 3-17.

Walker, M.J.C., Lowe, J.J. 1981. Postglacial environmental history of Rannoch Moor. III. Early and mid Flandrian pollen stratigraphic data from sites on western Rannoch Moor and near Fort William. Journal of Biogeography, 8, 475491.

Wastegård, S., Bjorck, S., Possnert, G. and Wohlfarth, B. 1998. Evidence of the occurance of Vedde Ash in Sweden: radiocarbon age estimates. Journal of Quaternary Science, 13, 271-274.

Wastegård, S., Turney, C. S. M., Lowe, J. J. \& Roberts, S. J. 2000. New discoveries of the Vedde Ash in southern Sweden and Scotland. Boreas, 29, 72-78

Wastegård, S., Bjorck, S., Grauert, M. and Hannon, G.E. 2001. The Mjauvotn tephra and other Holocene tephra horizons from the Faroe Islands: a link between the Icelandic source region, the Nordic Seas, and the European continent. The Holocene, 11, 101-109.

Wohlfarth, B., Blaauw, M., Davies, S.M., Andersson, M., Wastegård, S., Hormes, A., \& Possnert, G. 2006. Constraining the age of Lateglacial and early Holocene pollen zones and tephra horizons in southern Sweden with Bayesian probability methods. Journal of Quaternary Science, 21, 321-334.

Zillen, L.M., Wastegård, S. and Snowball, I.F. (2002) Calendar year ages of three mid-Holocene tephra layers identified in varved lake sediments in west central Sweden. Quaternary Science Reviews, 21, 1583-1591. 


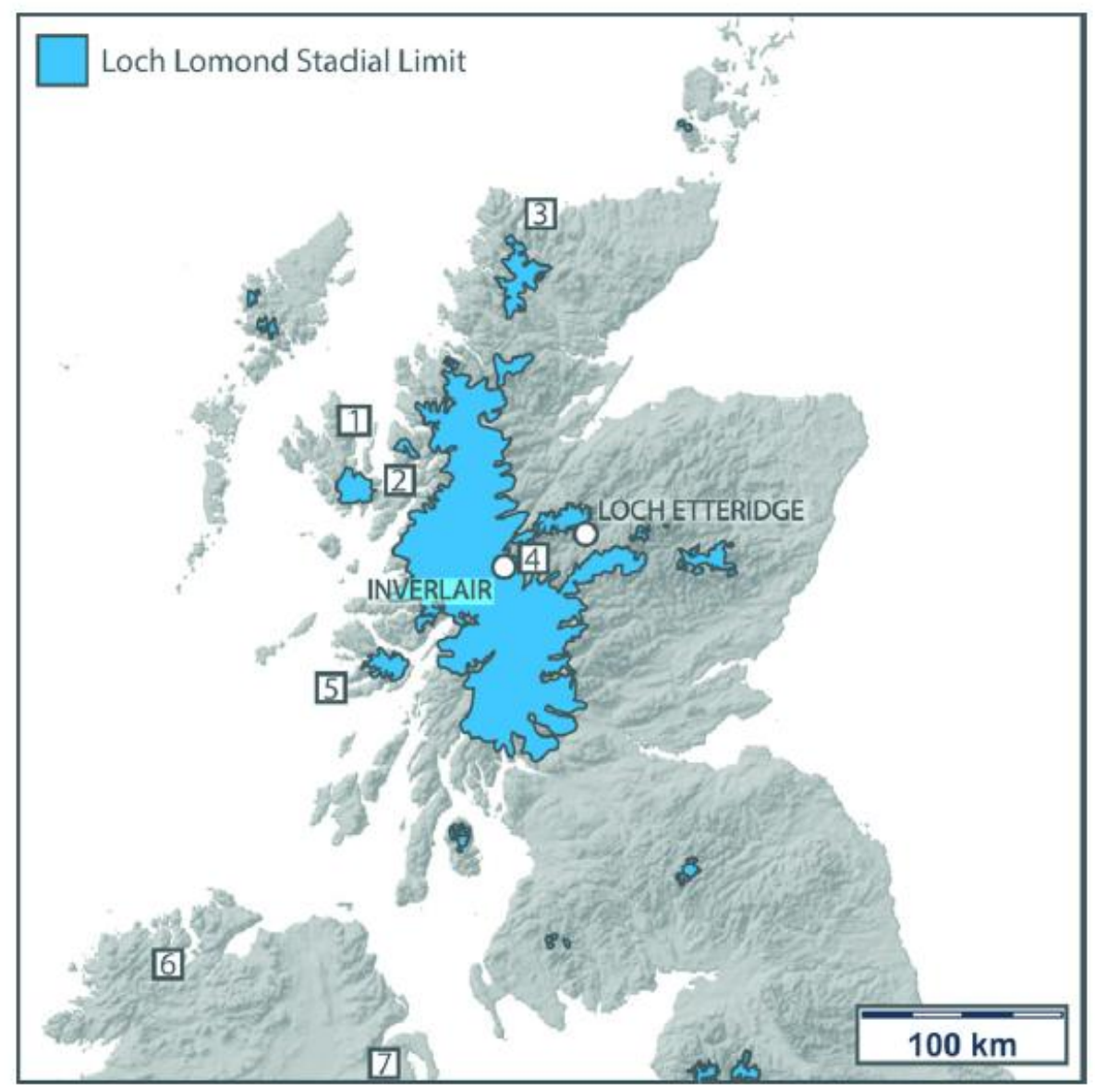

Fig. 1. Map showing generalised maximum limits of Loch Lomond Readvance ice and the approximate positions of the Inverlair and Loch Etteridge sites, and of seven other sites known to contain early Holocene tephra layers (1, 2, 5: Druim Loch, Loch Ashik, Loch an t'Suidhe [Pyne-O’Donnell, 2007]; 3: An Druim Loch [Ranner et al., 2005]; 4: Loch Laggan [MacLeod, 2008]; 6,7: Lough Nadourcan, Long Lough [Turney et al., 2006]). The glaciation limits are based on Golledge (2010), Boston (2012), Brown et al. (2013) and Pearce et al. (2014). 

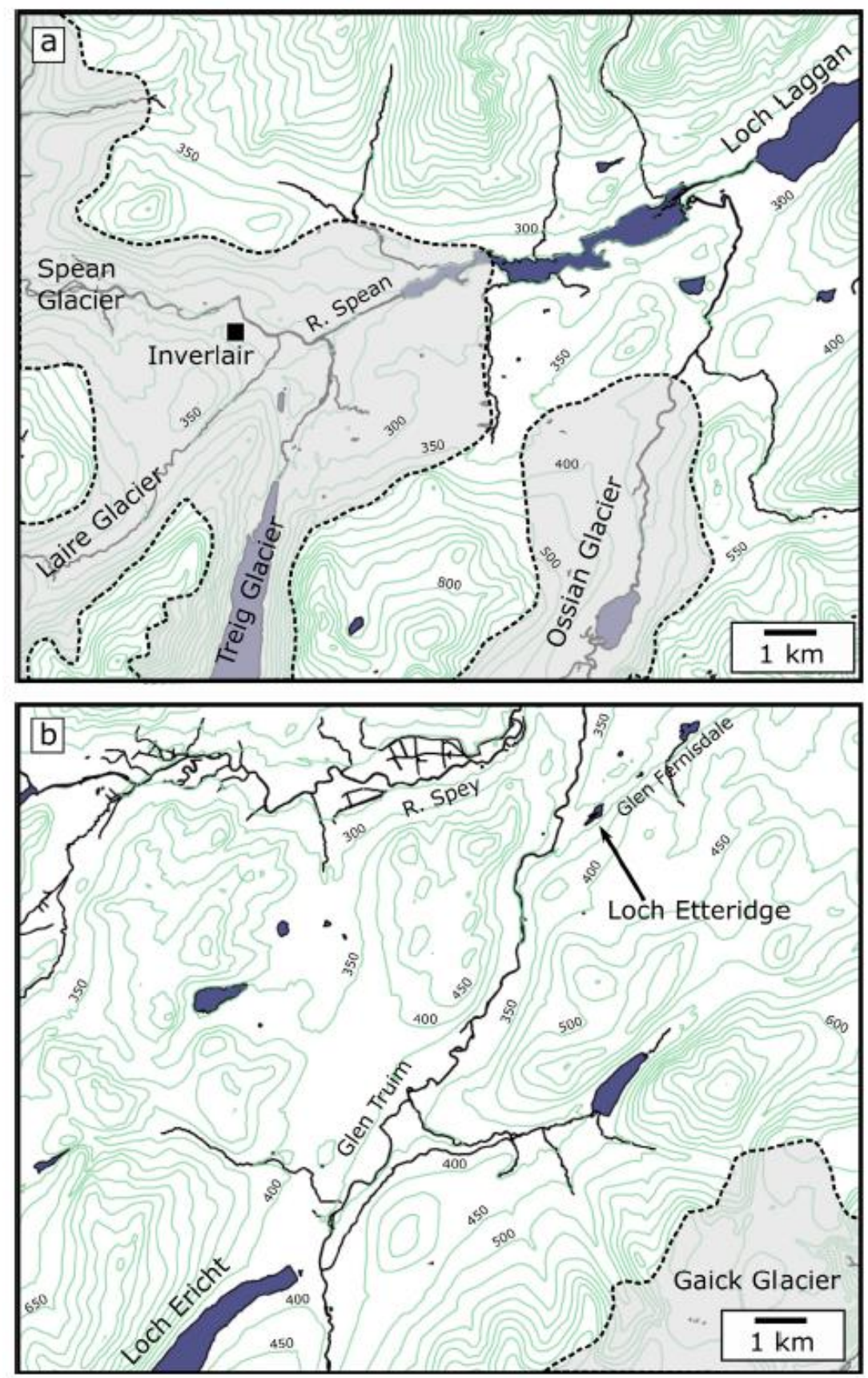

Fig. 2. (a) Location of the Inverlair kettle-hole site shown in relation to the maximum limits of Loch Lomond Readvance ice in the district of Lochaber, Scotland, based on Sissons (1979a). (b) Location of Loch Etteridge, which lies near the head of a tributary valley of the River Spey: the loch drains north-eastwards, through Glen Fernisdale. The site also lies north of the Loch Lomond Readvance limits mapped for this region, by Sissons (1974) for the Gaick Plateau, and by Benn and Ballantyne (2005) for the West Drumochter Hills (to the south of Loch Ericht), the northern limit of which lies just off the bottom edge of the diagram (drawn using OS data Crown copyright [2015]). 


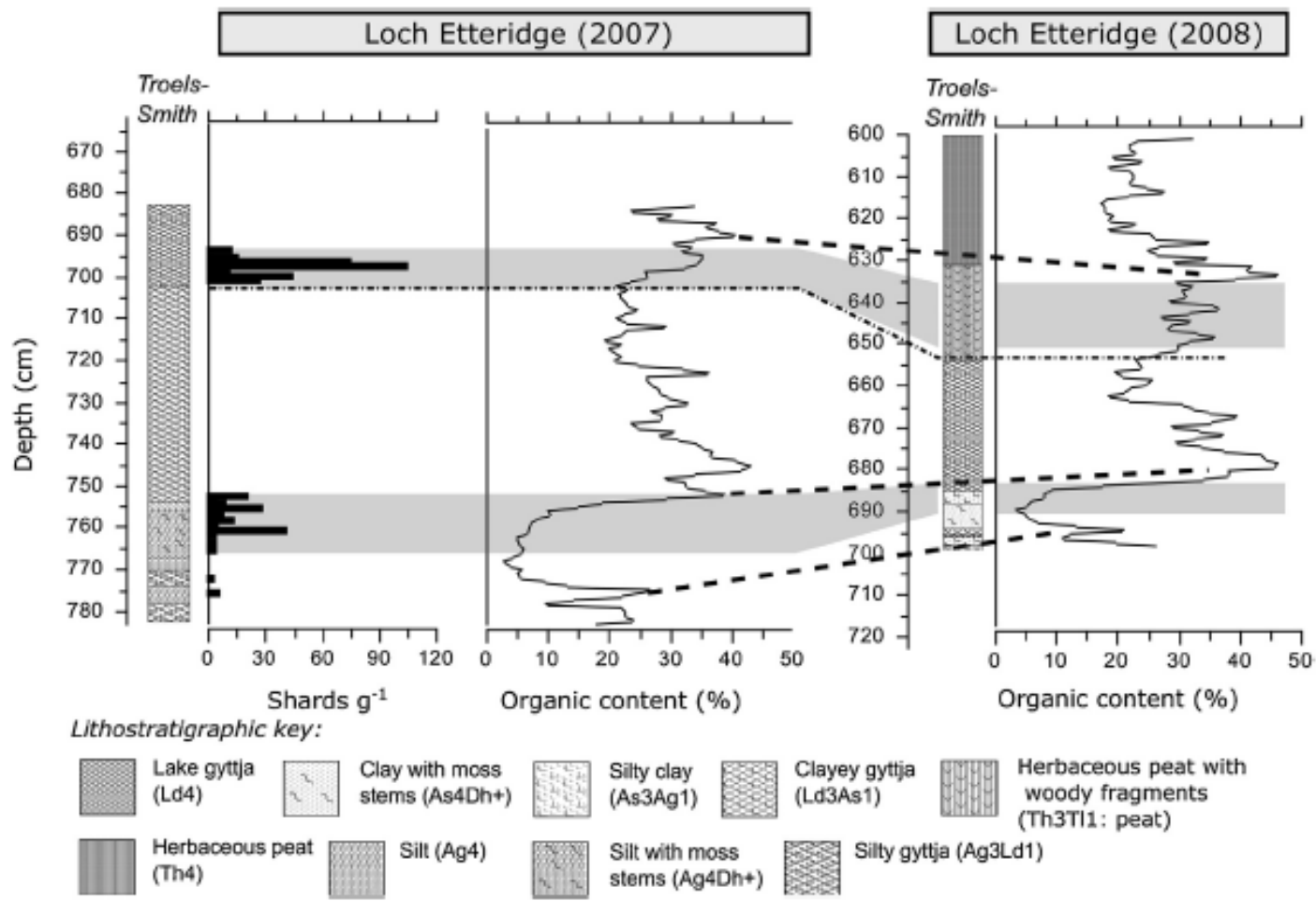

Fig. 3. Alignment of the two sequences studied from Loch Etteridge based on organic content (\%) determined through loss-on-ignition (dashed black line) and lithostratigraphy (Troels-Smith, patterned black line). Cryptotephra analysis was undertaken on the core collected in 2007 (tephra shard abundance shown in shards g_1), while pollen analysis was undertaken on the core collected in 2008 (see Fig. 4).

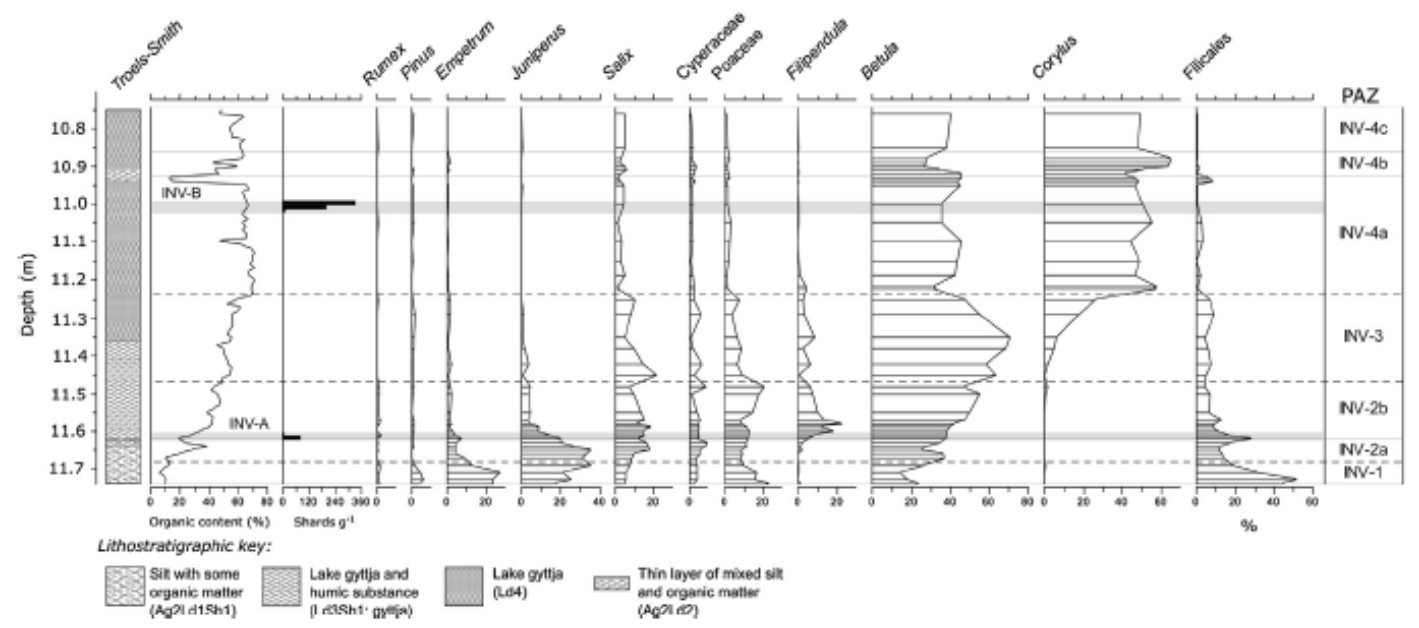

Fig. 4. Summary pollen percentage data for Inverlair (2010) shown alongside lithostratigraphic units (based on Troels-Smith), loss-on-ignition and rhyolitic shard counts (shards g_1). Fern spores are shown on the right and were not included in the main pollen sum.

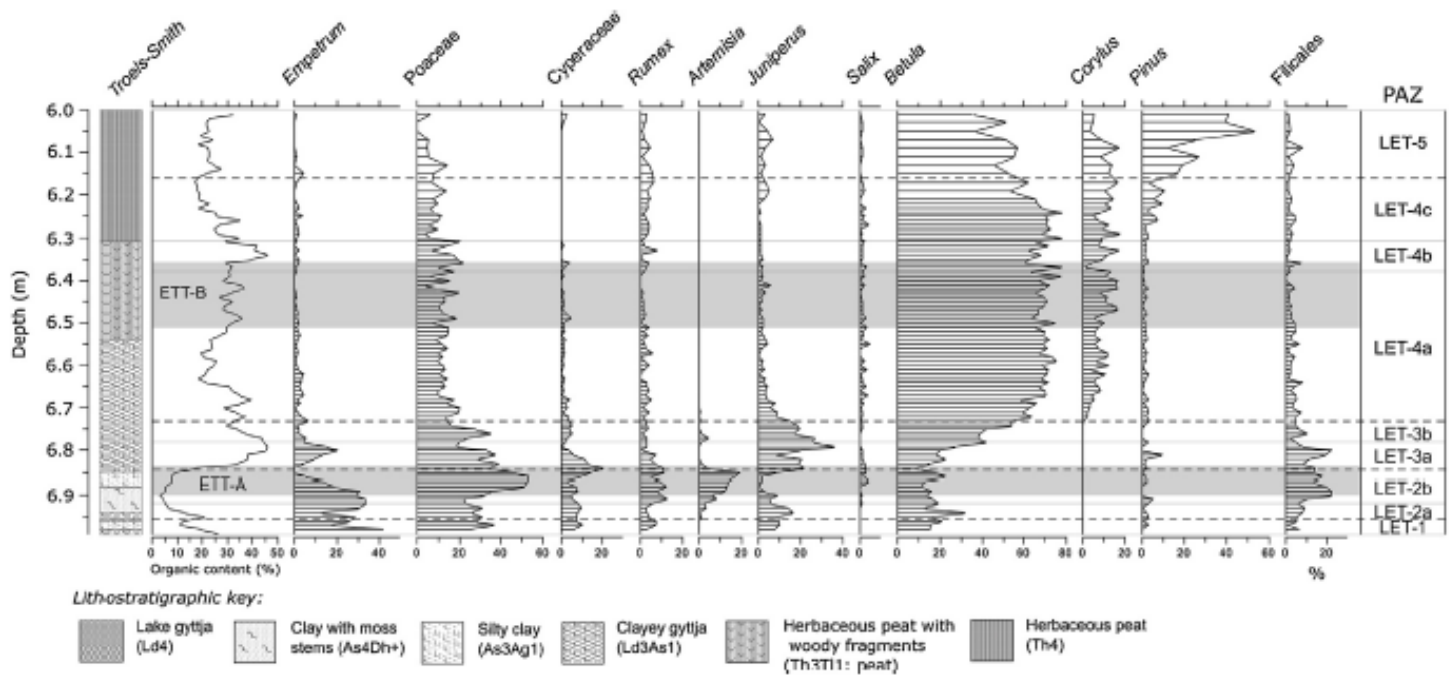

Fig. 5. Summary pollen percentage data for Loch Etteridge (2008) shown alongside loss-on-ignition and positions of tephra layers. Fern spores are shown on the right and were not included in the main pollen sum. 


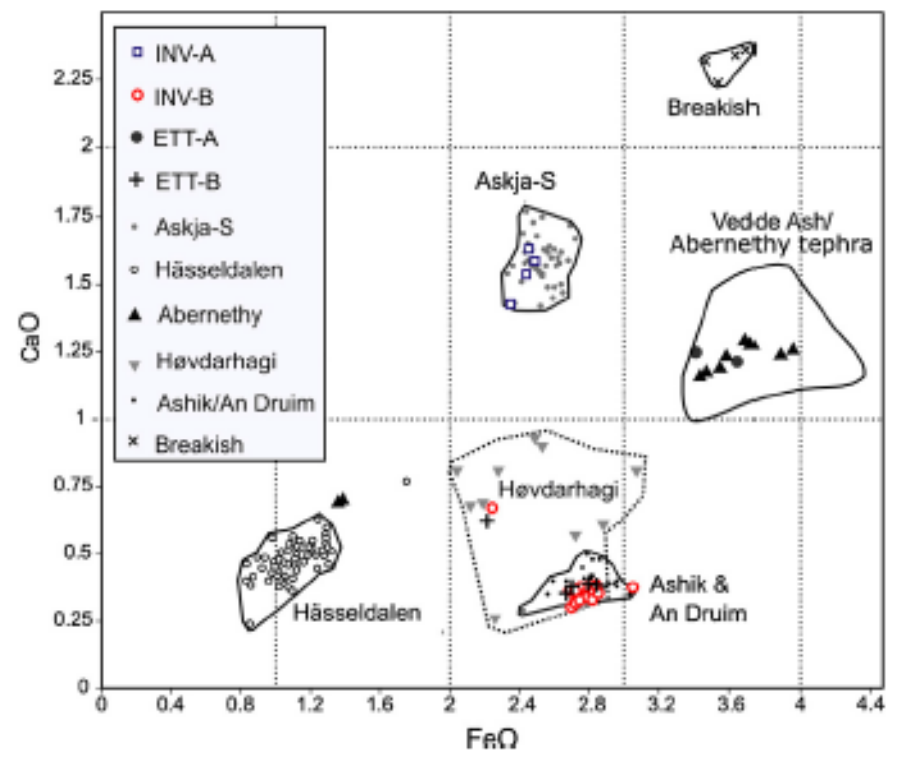

Fig. 6. Plot showing $\mathrm{CaO}$ vs $\mathrm{FeO}$ content for glass shards recovered from the Inverlair and Loch Etteridge sequences with geochemical envelopes illustrated for several other known Late Glacial and early Holocene tephras: Abernethy (Matthews et al., 2011), Ashik and An Druim (Ranner et al., 2005; Pyne-O’Donnell, 2007), Askja (Davies et al., 2003; Pilcher et al., 2005; Turney et al., 2006; Lind and Wastega ${ }^{\circ}$ rd, 2011), Breakish (Pyne-O’Donnell, 2007), Høvdarhagi (Lind and Wastega ${ }^{\circ}$ rd, 2011), and Ha“sseldalen (Davies et al., 2003; Lind and Wastega ${ }^{\circ}$ rd, 2011; Lilja et al., 2013). Individual points were omitted for the rhyolitic component of the Vedde Ash due to the larger quantity of data available (Mangerud et al., 1984; Turney et al., 1997; Wastega ${ }^{\circ}$ rd et al., 1998, 2000; Bjo“" rck and Wastega ${ }^{\circ}$ rd, 1999; Zillen et al., 2002; Pilcher et al., 2005; Koren et al., 2008). Note: data have not been normalised.
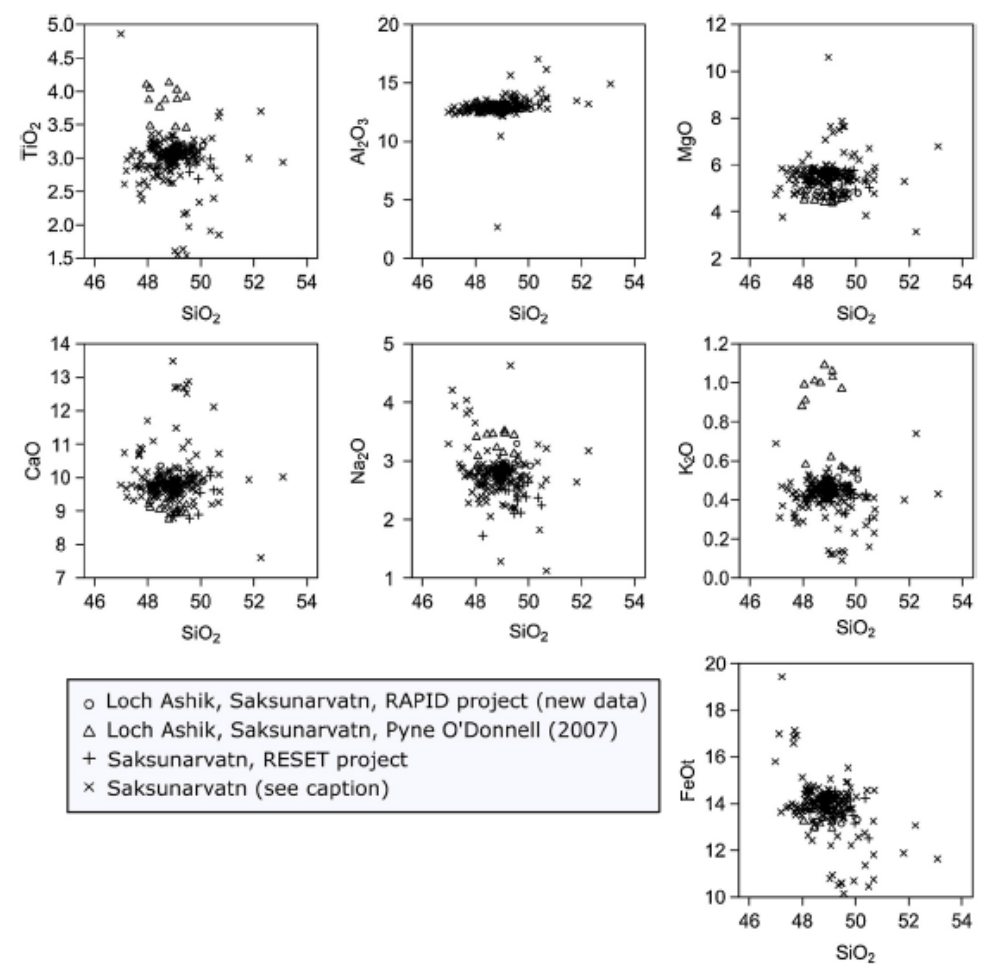

Fig. 7. Major element Harker Variation plot for the Saksunarvatn Ash reported at Loch Askik (Pyne-O'Donnell, 2007) against the revised chemistry for this tephra from the RAPID project (reported chronologically in Brooks et al., 2012), against published chemistry for the Saksunarvatn (Mangerud et al., 1986; Bennett et al., 1992; Bunting, 1994; Wastega ${ }^{\circ}$ rd et al., 2001; Andrews et al., 2002; Lloyd et al., 2009; Bramham-Law et al., 2013). The RAPID data for the Ashik were analysed by WDS-EPMA carried out using the JEOL JXA8800 microprobe (Department of Earth Sciences at the University of Oxford). See Table S2 in the supporting information for raw data and details of analytical standards. 
Table 1

Major oxide concentrations of rhyolitic shards from Inverlair as determined using EPMA (JEOL-8600 electron microprobe; beam diameter $10 \mu \mathrm{m}$ ). Depths indic ate the points from which the samples were taken for analysis (not the overall spread of the peak). Totals below 928 have not been shown.

\begin{tabular}{|c|c|c|c|c|c|c|c|c|c|c|}
\hline Shard & $\mathrm{SiO}_{2}$ & $\mathrm{TiO}_{2}$ & $\mathrm{Al}_{2} \mathrm{O}_{3}$ & $\mathrm{FeO}$ & $\mathrm{MnO}$ & Mgo & $\mathrm{CaO}$ & $\mathrm{Na}_{2} \mathrm{O}$ & $\mathrm{K}_{2} \mathrm{O}$ & Total \\
\hline \multicolumn{11}{|c|}{$10.99-11.00 \mathrm{~m}$} \\
\hline \multicolumn{11}{|c|}{ NVV-B (An Druim) } \\
\hline 1 & 70.73 & 0.16 & 11.76 & 2.69 & 0.16 & 0.04 & 0.36 & 4.93 & 4.37 & 95.2 \\
\hline 2 & 71.85 & 0.19 & 12.02 & 2.79 & 0.09 & 0.02 & 0.38 & 5.33 & 4.45 & 97.13 \\
\hline 3 & 70.06 & 0.24 & 11.8 & 2.7 & 0.08 & 0.07 & 0.3 & 4.79 & 4.29 & 94.34 \\
\hline 4 & 71.06 & 0.22 & 11.86 & 2.73 & 0.07 & 0.05 & 0.33 & 5.11 & 4.36 & 95.78 \\
\hline 5 & 70.15 & 0.16 & 11.62 & 2.83 & 0.02 & 0.06 & 0.36 & 4.95 & 4.16 & 94.31 \\
\hline 6 & 70.5 & 0.17 & 11.75 & 2.85 & 0.11 & 0.02 & 0.35 & 5.16 & 4.21 & 95.13 \\
\hline 7 & 69.57 & 0.2 & 12.1 & 2.79 & 0.09 & 0.03 & 0.34 & 5.19 & 4.27 & 94.57 \\
\hline 8 & 69.03 & 0.14 & 11.55 & 2.73 & 0.04 & 0.04 & 0.35 & 4.97 & 4.39 & 93.24 \\
\hline 9 & 70.96 & 0.16 & 11.74 & 2.75 & 0.05 & 0.06 & 0.38 & 4.92 & 4.22 & 95.23 \\
\hline 10 & 70.43 & 0.17 & 11.88 & 2.72 & 0.16 & 0 & 0.32 & 4.92 & 4.42 & 95.02 \\
\hline 11 & 69.89 & 0.21 & 11.55 & 2.72 & 0.06 & 0.02 & 0.36 & 5.24 & 4.22 & 94.29 \\
\hline 12 & 70.66 & 0.24 & 11.78 & 2.82 & 0.06 & 0.04 & 0.33 & 4.97 & 4.31 & 95.22 \\
\hline 13 & 70.31 & 0.24 & 11.72 & 3.05 & 0.08 & 0.06 & 0.38 & 4.85 & 4.35 & 95.01 \\
\hline 14 & 70.31 & 0.15 & 11.68 & 2.74 & 0.06 & 0.06 & 0.33 & 4.76 & 4.36 & 94.45 \\
\hline Mean & 70.39 & 0.19 & 11.77 & 2.78 & 0.08 & 0.04 & 0.35 & 5.01 & 4.31 & 94.92 \\
\hline $1 \sigma$ & 0.68 & 0.04 & 0.16 & 0.09 & 0.04 & 0.02 & 0.02 & 0.17 & 0.09 & 0.89 \\
\hline \multicolumn{11}{|c|}{$10.99-11.00 \mathrm{~m}$} \\
\hline \multicolumn{11}{|c|}{ INV-B (Hevdarhagi/An Druim) } \\
\hline 15 & 67.35 & 0.18 & 13.01 & 2.24 & 0.06 & 0.10 & 0.67 & 5.21 & 4.07 & 92.90 \\
\hline \multicolumn{11}{|c|}{$\begin{array}{l}11.61-11.62 \mathrm{~m} \\
\text { NY-A (Askia-S) }\end{array}$} \\
\hline 1 & 74.09 & 0.34 & 12.01 & 2.46 & 0.08 & 0.24 & 1.63 & 4.20 & 2.53 & 97.57 \\
\hline 2 & 73.06 & 0.27 & 11.71 & 2.49 & 0.08 & 0.25 & 1.59 & 4.46 & 2.46 & 96.36 \\
\hline 3 & 70.41 & 0.28 & 11.47 & 2.35 & 0.00 & 0.25 & 1.42 & 3.93 & 2.43 & 92.55 \\
\hline 4 & 70.64 & 0.26 & 11.57 & 2.44 & 0.09 & 0.22 & 1.54 & 4.10 & 2.46 & 93.31 \\
\hline Mean & 72.05 & 0.29 & 11.69 & 2,44 & 0.06 & 0.24 & 1.55 & 4.17 & 2.47 & 94.95 \\
\hline $1 \sigma$ & 1.81 & 0.04 & 0.23 & 0.06 & 0.04 & 0.01 & 0.09 & 0.22 & 0.04 & 2.40 \\
\hline
\end{tabular}

Table 1 Major oxide concentrations of rhyolitic shards from Inverlair as determined using EPMA (JEOL-8600 electron microprobe: beam diameter $10 \mathrm{~mm}$ ). Depths indicate the points from which the samples were taken for analysis (not the overall spread of the peak). Totals below $92 \%$ have not been shown.

Table 2

Major oxide concentrations of tephra shards from Loch Etteridge (2007) as determined using EPMA (JEOL-8600 electron microprobe: beam diameter $10 \mu \mathrm{m}$ ).

\begin{tabular}{|c|c|c|c|c|c|c|c|c|c|c|}
\hline Shard & $\mathrm{SiO}_{2}$ & $\mathrm{TiO}_{2}$ & $\mathrm{Ab}_{2} \mathrm{O}_{3}$ & $\mathrm{FeO}$ & MnO & $\mathrm{MgO}$ & $\mathrm{CaO}$ & $\mathrm{Na}_{2} \mathrm{O}$ & $\mathrm{K}_{2} \mathrm{O}$ & Total \\
\hline \multicolumn{11}{|c|}{$\begin{array}{l}6.98-6.99 m \\
\text { LET-B (Ashik/An Druim) }\end{array}$} \\
\hline 1 & 72.43 & 0.22 & 12.30 & 2.80 & 0.06 & 0.04 & 0.39 & 4.74 & 4.43 & 97.42 \\
\hline 2 & 71.19 & 0.20 & 12.02 & 2.68 & 0.06 & 0.05 & 0.36 & 4.41 & 4.21 & 95.16 \\
\hline 3 & 70.79 & 0.18 & 11.95 & 2.84 & 0.02 & 0.06 & 0.39 & 4.62 & 4.29 & 95.14 \\
\hline 4 & 70.56 & 0.20 & 12.05 & 2,70 & 0.09 & 0.03 & 0.38 & 4.26 & 4.30 & 94.57 \\
\hline Mean & 71.24 & 0.20 & 12.08 & 2.76 & 0.06 & 0.05 & 0.38 & 4.51 & 4.31 & 95.57 \\
\hline $1 \sigma$ & 0.83 & 0.02 & 0.15 & 0.08 & 0.03 & 0.01 & 0.01 & 0.21 & 0.09 & 1.26 \\
\hline \multicolumn{11}{|c|}{$\begin{array}{l}\text { 6.98-6.99m } \\
\text { LET-B (Høvdarhagi/An Druim) }\end{array}$} \\
\hline 5 & 68.66 & 0.17 & 14.11 & 2.22 & 0.02 & 0.12 & 0.63 & 4.71 & 4.47 & 95.10 \\
\hline \multicolumn{11}{|c|}{$\begin{array}{l}7.61-7.62 \mathrm{~m} \\
\text { LET-A (Vedde Ash) }\end{array}$} \\
\hline 1 & 70.51 & 0.25 & 13.55 & 3.65 & 0.14 & 0.20 & 1.22 & 4.62 & 3.65 & 97.78 \\
\hline 2 & 68.50 & 0.28 & 13.30 & 3.41 & 0.12 & 0.22 & 1.25 & 4.24 & 3.27 & 94.60 \\
\hline
\end{tabular}

Table 2 Major oxide concentrations of tephra shards from Loch Etteridge (2007) as determined using EPMA (JEOL-8600 electron microprobe: beam diameter $10 \mathrm{~mm})$.

Table 3

Summary scheme showing relative succession of pollen-stratigraphic changes at Inverlair and Loch Etteridge with respect to dated tephra layers. Lines denote the three tephra layers.

\begin{tabular}{|c|c|c|c|}
\hline Tephrostratigraphy & Chronology & Inverlair & Loch Etteridge \\
\hline Post-An Dnuim & $<9781-9538$ & $\begin{array}{l}\text { Betula-Coryhus } \\
\text { Betula-Coryhus }\end{array}$ & Betula-Coryhus \\
\hline $\begin{array}{l}\text { Post-Ashya } \\
\text { Pre-An Druim }\end{array}$ & $\begin{array}{r}>9781-9538 \\
<10,944-10,716\end{array}$ & $\begin{array}{l}\text { Betula-Coryhus } \\
\text { Betula dominant, Corylus rise }\end{array}$ & $\begin{array}{l}\text { Betula-Coryhus } \\
\text { Betula dominant, Corylus rise }\end{array}$ \\
\hline $\begin{array}{l}\text { Pre-Asha } \\
\text { Post-Abernethy }\end{array}$ & $\begin{array}{l}>10,944-10,716 \\
<11,720-11,230\end{array}$ & $\begin{array}{l}\text { Junipenus peak } \\
\text { Junipenus rise }\end{array}$ & $\begin{array}{l}\text { Junipenus peak } \\
\text { junipens rise }\end{array}$ \\
\hline Pre-Abernethy & & Empetrum peak & Empetrum peak \\
\hline
\end{tabular}

Table 3 Summary scheme showing relative succession of pollen-stratigraphic changes at Inverlair and Loch Etteridge with respect to dated tephra layers. Lines denote the three tephra layers. 